\title{
CORRECTION
}

\section{Correction to: Activation of Notch-1 in oral epithelial cells by $P$. gingivalis triggers the expression of the antimicrobial protein $\mathrm{PLA}_{2}$-IIA}

Ahmad Al-Attar ${ }^{1}$, Yelena Alimova ${ }^{1}$, Sreenatha Kirakodu ${ }^{1}$, Anastasia Kozal ${ }^{1}$, Michael John Novak ${ }^{1}$, Arnold J. Stromberg ${ }^{2}$, Luis Orraca ${ }^{3}$, Janis Gonzalez-Martinez ${ }^{4}$, Melween Martinez ${ }^{4}$, Jeffrey L. Ebersole ${ }^{5}$ and Octavio A. Gonzalez ${ }^{1,6}$

Mucosal Immunology (2019) 12:1066; https://doi.org/10.1038/s41385-019-0152-6

Correction to: Mucosal Immunology (2018) 11(4): 1047-1059; https://doi.org/10.1038/s41385-018-0014-7; published online 07 March 2018
The sequence for the Reverse primer used to amplify the human gene PLA2G2A presented in table 1 is incorrect. The following, is the correct sequence: Reverse $5^{\prime}$ - GCTCCCTCTGCAGT GTTATT -3'

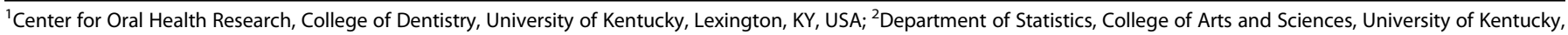

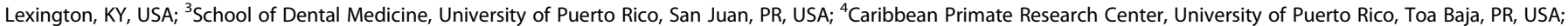

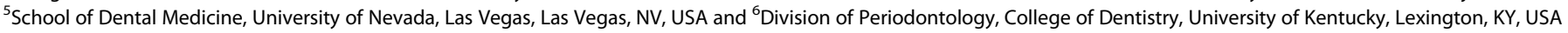
Correspondence: Octavio A. Gonzalez (octavio.gonzalez@uky.edu)

Published online: 22 February 2019 